\title{
The effect of vitamin C on bronchoconstriction and respiratory symptoms caused by exercise: a review and statistical analysis
}

\author{
Harri Hemilä
}

\begin{abstract}
Physical activity increases oxidative stress and therefore the antioxidant effects of vitamin $\mathrm{C}$ administration might become evident in people undertaking vigorous exercise. Vitamin $C$ is involved in the metabolism of histamine, prostaglandins, and cysteinyl leukotrienes, all of which appear to be mediators in the pathogenesis of exercise-induced bronchoconstriction (EIB). Three studies assessing the effect of vitamin C on patients with EIB were subjected to a meta-analysis and revealed that vitamin C reduced postexercise $\mathrm{FEV}_{1}$ decline by $48 \%$ (95\% Cl: $33 \%$ to $64 \%$ ). The correlation between postexercise $\mathrm{FEV}_{1}$ decline and respiratory symptoms associated with exercise is poor, yet symptoms are the most relevant to patients. Five other studies examined subjects who were under short-term, heavy physical stress and revealed that vitamin C reduced the incidence of respiratory symptoms by 52\% (95\% $\mathrm{Cl}$ : $36 \%$ to $65 \%$ ). Another trial reported that vitamin C halved the duration of the respiratory symptoms in male adolescent competitive swimmers. Although $\mathrm{FEV}_{1}$ is the standard outcome for assessing ElB, other outcomes may provide additional information. In particular, the mean postexercise decline of $\mathrm{FEF}_{50}$ is twice the decline of $\mathrm{FEV}_{1}$. Schachter and Schlesinger (1982) reported the effect of vitamin C on exercise-induced FEF 60 levels in 12 patients suffering from EIB and their data are analyzed in this paper. The postexercise $\mathrm{FEF}_{60}$ decline was greater than $60 \%$ for five participants and such a dramatic decline indicates that the absolute postexercise $\mathrm{FEF}_{60}$ level becomes an important outcome in its own right. Vitamin C increased postexercise $\mathrm{FEF}_{60}$ levels by 50\% to 150\% in those five participants, but had no significant effect in the other seven participants. Thus, future research on the effects of vitamin C on ElB should not be restricted to measuring only FEV ${ }_{1}$. Vitamin $C$ is inexpensive and safe, and further study on those people who have EIB or respiratory symptoms associated with exercise is warranted.
\end{abstract}

Keywords: Anti-asthmatic agents, Ascorbic acid, Cough, Histamine, Exercise-induced asthma, Forced expiratory flow rates, Meta-analysis, Prostaglandin, Randomized controlled trial, The lungs

\section{Introduction}

Exercise-induced bronchoconstriction (EIB) describes the acute narrowing of the airways that occurs as a result of vigorous exercise [1-3]. The emergence of EIB depends on the kind and level of physical activity, and also on the humidity and temperature of the inhaled air [1-3].

Only about $10 \%$ of the non-asthmatic general population suffer from EIB, whereas up to $90 \%$ of asthmatics may suffer from EIB [2-4]. Thus EIB is a common phenotype of asthma. EIB is also common among competitive athletes even if they do not have asthma, and it is

Correspondence: harri.hemila@helsinki.fi

Department of Public Health, POB 41 University of Helsinki, Mannerheimintie 172, FIN-00014 Helsinki, Finland particularly prevalent in endurance sports, such as running, winter sports and swimming $[2,3,5]$.

Usually, a decline of $10 \%$ or greater in $\mathrm{FEV}_{1}$ after exercise is classified as EIB, but other cut off limits have also been used [1-3]. However, EIB is not an arbitrary dichotomous condition, instead there is a continuous variation in the possible level of $\mathrm{FEV}_{1}$ decline such that the $9 \%$ and $11 \%$ decline levels in $\mathrm{FEV}_{1}$ are not biologically different phenomena, although they fall on either side of the usual cut off level. A single constant percentage point cut off limit is thus simplistic. It is more useful to analyze the phenomenon as a continuous variable rather than a dichotomous variable. This issue is relevant when 
planning appropriate statistical analysis of outcomes related to EIB.

Symptoms are much more important than laboratory values for patients. However, the correlation between the declines in postexercise $\mathrm{FEV}_{1}$ values and postexercise respiratory symptoms is poor $[4,6,7]$. Therefore, respiratory symptoms should be recorded concurrently with the pulmonary function tests.

The stimulus for EIB seems to be the loss of water caused by increased ventilation. This leads to the release of mediators such as histamine, prostaglandins and leukotrienes, all of which cause bronchoconstriction [1-3,8]. Nitric oxide also plays a role in the pathogenesis of EIB $[9,10]$. Finally, oxidative stress seems to play role in the emergence of EIB $[11,12]$.

\section{Vitamin C: exercise and airways}

Physical activity increases oxidative stress [13], and therefore, as an antioxidant vitamin $\mathrm{C}$ might have particularly evident effects in people who are participating in vigorous exercise. Electron spin resonance studies have shown that vitamin $\mathrm{C}$ administration decreased the levels of free radicals generated during exercise $[14,15]$ and vitamin $\mathrm{C}$ administration attenuated the increases in oxidative stress markers caused by exercise [16-18].

The level of vitamin $C$ in the lungs is high [19], and vitamin $\mathrm{C}$ levels in alveolar macrophages and alveolar type II cells are 30 times higher than in plasma [20]. About $10 \%$ of vitamin $\mathrm{C}$ in the lungs of rats is in a lavageable form [21], but the level of vitamin $C$ in the bronchoalveolar lavage seems to be lower in humans than in rats [22]. In any case, high levels of vitamin $C$ in the lungs imply that the vitamin may protect the lungs against oxidative stress.

Unlike guinea pigs and humans, mice and rats are able to synthesize vitamin $C$, and these species are able to increase their rates of vitamin $C$ synthesis under certain stressful conditions. Ozone exposure in rats and mice significantly increased vitamin $\mathrm{C}$ levels in bronchoalveolar lavage fluid $[23,24]$, which might serve as a protective response to the higher oxidative stress level being encountered. Exposure to ozone and nitrogen dioxide decreased lung vitamin $C$ levels in guinea pigs, which implies that the vitamin was consumed while it protected against the oxidants $[25,26]$. Vitamin $C$ administration in guinea pigs decreased mortality caused by ozone exposure $[27,28]$ and vitamin $C$ deficiency in guinea pigs increased necrotic injury to type II lung cells upon $\mathrm{H}_{2} \mathrm{O}_{2}$ treatment [29]. Exposure to ozone in humans decreased the vitamin $\mathrm{C}$ level in the respiratory tract lining fluid [30]. Thus, given that oxidative stress seems to play a role in EIB [11,12], vitamin C might protect against EIB through non-specific antioxidant effects. Nevertheless, there are also more specific biochemical mechanisms through which vitamin $\mathrm{C}$ may influence pulmonary functions.

Histamine is one of the mediators involved in the pathogenesis of EIB $[1-3,8]$. It is released from mast cells, which have a high concentration of vitamin C [31]. Furthermore, the release of histamine causes oxidation of vitamin $C$ in the mast cells [32]. In guinea pigs, a deficiency of vitamin $\mathrm{C}$ increased histamine levels in their plasma, urine and lungs [33,34], whereas a high dosage of vitamin $\mathrm{C}$ decreased their plasma histamine levels [35]. In vitamin $C$ deficient guinea pigs, a single dose of vitamin $C$ rapidly decreased plasma and urine histamine levels to normal levels [34]. In rats, vitamin $C$ attenuated the increases in histamine levels, which were caused by various stressful conditions including cold and heat stress [36]. Four trials conducted on humans found that the administration of vitamin $\mathrm{C}$ significantly decreased plasma histamine levels [37-40]. Vitamin C decreased bronchoconstriction caused by histamine in living guinea pigs [33,41-44], and it decreased contractions caused by histamine in isolated guinea pig trachea smooth muscle $[45,46]$. Finally, in guinea pigs exposed to ozone, vitamin C decreased bronchial reactivity to histamine [47].

Prostaglandins (PGs) and leukotrienes (LTs) also participate in the pathogenesis of EIB [1-3,8]. Vitamin C deficiency in guinea pigs increased the level of bronchoconstrictor $\mathrm{PGF}_{2 \alpha}$ in the trachea $[44,48]$, and increased the in vitro synthesis of $\mathrm{PGF}_{2 \alpha}$ in lung microsomes [49]. Vitamin C deficiency decreased the production of $\mathrm{PGE}_{2}$ in guinea pig trachea [48]; $\mathrm{PGE}_{2}$ causes smooth muscle relaxation and may protect against EIB $[1,2]$. Furthermore, hyperresponsiveness to histamine in vitamin $C$ deficient guinea pigs was further increased by indomethacin [44], and the relaxing effects of vitamin $C$ on isolated guinea pig trachea were inhibited by indomethacin [46]. Indomethacin also blocked the effect of vitamin $\mathrm{C}$ on methacholine-induced bronchoconstriction in humans [50]. The influence of indomethacin on vitamin $\mathrm{C}$ effects is a further indication that the pulmonary effects of vitamin $\mathrm{C}$ may be partly mediated through the influences of vitamin $\mathrm{C}$ on the PG metabolism. Furthermore, vitamin $C$ decreased contractions caused by $\mathrm{PGF}_{2 \alpha}$ in guinea pig tracheal tube preparations [48]. Finally, the administration of vitamin $C$ in humans reduced the postexercise increase in the urinary markers of bronchoconstrictors $\mathrm{PGD}_{2}$ and cysteinyl LTs [51].

Nitric oxide (NO) has also been implicated in the pathogenesis of EIB $[9,10]$. The metabolism of NO is altered in EIB patients but it is not correlated with exercise-induced changes in spirometry [9]. Vitamin $C$ was reported to decrease the NO level in EIB patients [51].

A single oral dose of vitamin $\mathrm{C}$ can rapidly elevate mucosal vitamin $C$ levels. Nasal lavage fluid vitamin $C$ levels in human subjects increased by three-fold in two 
hours after a single dose of 1 or $2 \mathrm{~g}$ of vitamin $C$ [52,53]. The rapid transport of ingested vitamin $\mathrm{C}$ to the respiratory tract lining fluid implies that even single doses of vitamin $\mathrm{C}$ might be effective in protecting against acute increases in oxidative stress in the airways.

\section{$\mathrm{FEV}_{1}$ decline caused by exercise}

Three randomized, double-blind, placebo-controlled crossover trials examined the effect of vitamin C (0.5 to $2 \mathrm{~g} /$ day) on exercise-induced $\mathrm{FEV}_{1}$ decline (Table 1 ). The pooled effect of vitamin $C$ (Figure 1) indicates a reduction in the postexercise $\mathrm{FEV}_{1}$ decline of $48 \%$ (95\% CI: $33 \%$ to $64 \%$ ) $[54,55]$. In one study, Tecklenburg et al. reported that the postexercise $\mathrm{FEV}_{1}$ decline was $12.9 \%$ after the placebo period, but only $6.4 \%$ after a 2 -week vitamin $C$ administration, which corresponds to $50 \%$ reduction in the postexercise $\mathrm{FEV}_{1}$ decline [51] (Figure 1). In other two studies, vitamin $\mathrm{C}$ was administered as a single dose 1 or 1.5 hours before the exercise test [56,57], yet the effects were the same as for the first study (Figure 1). Thus, a single dose of vitamin $C$ before an exercise session appears to be sufficient to generate the same benefit as a 2-week supplementation regime. This may be explained by the rapid transfer of vitamin $\mathrm{C}$ to the airway lining fluids $[52,53]$.

The three EIB trials included a total of only 40 participants. However, the trials were carried out over three different decades and on two different continents. The criteria for EIB differed and the mean ages of the participants were 14 years in one study [57] but 25 and 26 years in the two other studies [51,56]. Nevertheless, all the studies are consistent with vitamin $\mathrm{C}$ halving the postexercise $\mathrm{FEV}_{1}$ decline (Figure 1). It is not clear how far this estimate can be generalized, but similar findings from such dissimilar studies indicate that vitamin $C$ may be effective for a wider population who suffer from EIB.

A fourth randomized cross-over trial on 8 participants who suffered from EIB found that the combination of $0.5 \mathrm{~g} /$ day of vitamin $C$ along with vitamin $\mathrm{E}$ significantly decreased the $\mathrm{FEV}_{1}$ decline at 5,15 and $30 \mathrm{~min}$ after exercise [58]. Although this finding is not specific to vita$\min C$, it is consistent with the benefits of antioxidants. In 5 other participants who did not suffer from EIB, postexercise $\mathrm{FEV}_{1}$ decline was not influenced by the combination of the vitamins [58]. This study was published only as an abstract.

Table 1 Trials on vitamin C and EIB

\begin{tabular}{|c|c|c|}
\hline \multicolumn{2}{|l|}{ Study [ref.] } & \multirow{2}{*}{$\begin{array}{l}\text { Characteristics of participants } \\
12 \text { subjects with asthma, selected from among employees of Yale University in the USA: } \\
\text { "all } 12 \text { subjects gave a characteristic description of EIB." All included participants had at } \\
\text { least } 20 \% \text { reduction in } \mathrm{FEF}_{60} \text { or } \mathrm{FEF}_{60(\mathrm{P})} \text { after exercise. }\end{array}$} \\
\hline Schachter \& Schlesinger [56] & Selection: & \\
\hline & Sex, age: & 5 Males, 7 Females; mean age 26 yr (SD 5 yr). \\
\hline & Exercise test: & $\begin{array}{l}\text { All subjects performed the exercise studies on a cycloergometer. Cardiac frequency was } \\
\text { measured with an electrocardiograph. Baseline heart rate was obtained and exercise was } \\
\text { begun at a constant speed of } 20 \mathrm{~km} / \mathrm{h} \text { against zero workload. At the end of each one } \\
\text { min interval cardiac frequency was measured and the workload was increased by } 150 \\
\text { kilopondmeters per min, keeping pedalling speed constant throughout the experiment. } \\
\text { Exercise against progressively larger workloads was continued until either the heart rate } \\
\text { reached } 170 \text { beats per min or the subject fatigued. Pulmonary function was assessed } \\
\text { post-exercise at } 0 \text { and } 5 \text { min. }\end{array}$ \\
\hline \multirow[t]{3}{*}{ Cohen et al. [57] } & Selection: & $\begin{array}{l}20 \text { patients with asthma in Israel. All of them demonstrated EIB by having a "decline of } \\
\text { at least } 15 \% \text { " in } \mathrm{FEV}_{1} \text { after a standard exercise test. }\end{array}$ \\
\hline & Sex, age: & 13 Males, 7 Females; mean age 14 yr (range 7 to 28 yr). \\
\hline & Exercise test: & $\begin{array}{l}\text { A 7-min exercise session using the treadmill. Each subject exercised to submaximal effort } \\
\text { at a speed and slope to provide } 80 \% \text { of the motional oxygen consumption as adjudged } \\
\text { by a pulse oximeter. Pulmonary function was assessed after an 8-min rest. }\end{array}$ \\
\hline \multirow[t]{3}{*}{ Tecklenburg et al. [51] } & Selection: & $\begin{array}{l}8 \text { subjects with asthma from a population of university students and the local community, } \\
\text { Indiana USA. All subjects had "documented ElB as indicated by a drop of greater than } \\
10 \% " \text { in postexercise FEV } 1 \text {. "All subjects had a history of chest tightness, shortness of breath } \\
\text { and intermittent wheezing following exercise." }\end{array}$ \\
\hline & Sex, age: & 2 Males, 6 Females; mean age 24.5 yr (SD 5 yr). \\
\hline & Exercise test: & $\begin{array}{l}\text { Each subject ran on a motorized treadmill which was elevated } 1 \% \text { per min until } 85 \% \text { of } \\
\text { age predicted maximum heart rate and ventilation exceeding } 40-60 \% \text { of predicted maximal } \\
\text { voluntary ventilation. Subjects maintained this exercise intensity for } 6 \text { min. Following the } \\
6 \text {-min steady state exercise, the grade of the treadmill continued to increase at } 1 \% \text { per } \\
\text { min until volitional exhaustion. Pulmonary function was assessed post-exercise at 1, 5, 10, } \\
15,20 \text {, and } 30 \text { min. The maximum percentage fall in FEV from the baseline (pre-exercise) } \\
\text { value was calculated and used as the outcome. }\end{array}$ \\
\hline
\end{tabular}




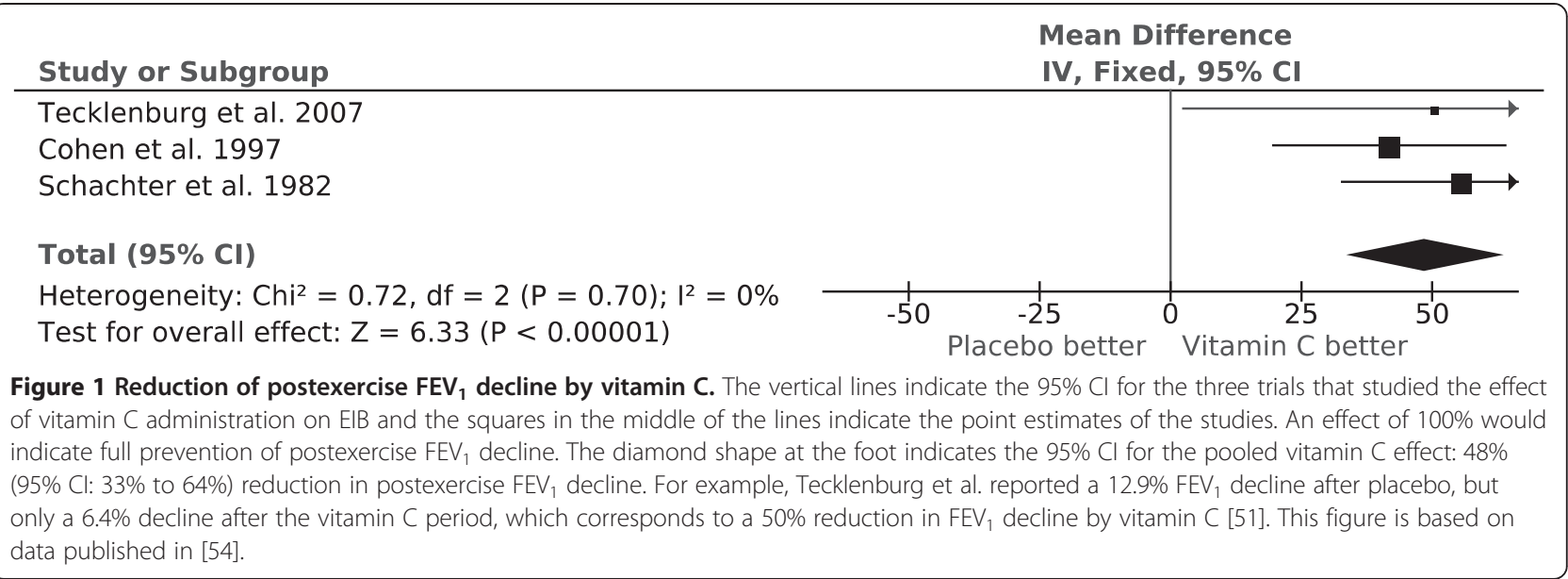

\section{$\mathrm{FEF}_{60}$ and PEF declines caused by exercise}

$\mathrm{FEV}_{1}$ is the standard outcome for assessing whether a patient suffers from EIB [1-3]. However, exercise-induced decline in $\mathrm{FEF}_{25-75}$ is twice as great as the decline in $\mathrm{FEV}_{1}$, and therefore, $\mathrm{FEF}_{25-75}$ may provide relevant information in addition to $\mathrm{FEV}_{1}$ data $[6,7,9,10,59-63]$. Furthermore, $\mathrm{FEF}_{50}$ values essentially give the same information as $\mathrm{FEF}_{25-75}$ [64].

Schachter and Schlesinger (1982) studied 12 participants with EIB and published the effects of a single dose of $0.5 \mathrm{~g}$ vitamin $\mathrm{C}$ on the $\mathrm{FEV}_{1}$, PEF, and $\mathrm{FEF}_{60}$ levels on each participant before and after the exercise test [56]. Figure 2 shows the data for 5 minutes after the exercise test. As a pulmonary function measure, the $\mathrm{FEF}_{60}$ level is close to the $\mathrm{FEF}_{50}$ level. On the basis of the slope of the linear regression line (Figure $2 \mathrm{~A}$ ), vitamin $\mathrm{C}$ decreased the postexercise $\mathrm{FEV}_{1}$ decline by $55 \%$ (95\% CI: $32 \%$ to $78 \%$ ). The mean decline in postexercise $\mathrm{FEV}_{1}$ was $18 \%$ on the placebo day. The greatest postexercise $\mathrm{FEV}_{1}$ decline on the placebo-day was $52 \%$ in participant \#11 (Figure 2A).

PEF is not recommended for assessing EIB, since it is less repeatable than $\mathrm{FEV}_{1}$ [2,3]. The study by Schachter and Schlesinger found that vitamin $C$ had no consistent effect on postexercise PEF decline (Figure 2B). The linear regression slope did not significantly differ from the null effect, thus it is not shown. However, all of the 5 participants who did benefit of vitamin $\mathrm{C}$ as measured by its effects on $\mathrm{FEV}_{1}$, also had a substantial postexercise PEF decline of $20 \%$ or more on the placebo day. Thus, a high PEF decline on the placebo day identified all the 5 participants who benefited from vitamin $\mathrm{C}$ as evaluated by $\mathrm{FEV}_{1}$. This finding might have practical importance since PEF measurements are much easier to carry out than spirometry.

The linear regression slope indicated that vitamin $C$ decreased the postexercise $\mathrm{FEF}_{60}$ decline by $58 \%$ (95\% CI: $23 \%$ to $92 \%$ ) (Figure $2 \mathrm{C}$ ). The mean decline in postexercise $\mathrm{FEF}_{60}$ was $35 \%$ on the placebo day, which is twice the decline in $\mathrm{FEV}_{1}$ (18\%). The ratio of about two for the declines in $\mathrm{FEF}_{25-75}$ and $\mathrm{FEV}_{1}$ has been reported previously $[6,7,9,10,62,63]$. The exercise-induced $\mathrm{FEF}_{60}$ decline on the placebo day was greater than $60 \%$ in 5 out of the 12 participants, with the greatest decline being $92 \%$ for participant \#11 (Figure 2C).

A dramatic postexercise $\mathrm{FEF}_{60}$ decline in 5 participants indicates that the absolute postexercise level of $\mathrm{FEF}_{60}$ becomes an important outcome in its own right. For each of these 5 participants, the postexercise $\mathrm{FEF}_{60}$ level was less than $1 \mathrm{~L} / \mathrm{s}$ on the placebo day (Figure 2D). Moreover, vitamin $\mathrm{C}$ administration increased the postexercise $\mathrm{FEF}_{60}$ level in these 5 participants by between $50 \%$ and $150 \%$. In contrast, no mean difference between the vitamin $C$ and placebo days was detected in the other 7 participants. This indicates that the effect of vitamin $\mathrm{C}$ may be restricted to those EIB patients who had postexercise $\mathrm{FEF}_{60}$ levels below $1 \mathrm{~L} / \mathrm{s}$.

Schachter and Schlesinger also reported the $\mathrm{FEF}_{60(\mathrm{P})}$ values, which were based on partial flow volume curves [56]. The effect of vitamin $\mathrm{C}$ on $\mathrm{FEF}_{60(\mathrm{P})}$ was similar to its effects on $\mathrm{FEF}_{60}$. This analysis is shown in Additional file 1.

Finally, Schachter and Schlesinger reported the $\mathrm{FEV}_{1}$, PEF, $\mathrm{FEF}_{60}$ and $\mathrm{FEF}_{60(\mathrm{P})}$ values also for the time point immediately after the exercise $(0 \mathrm{~min})$ [56]. At the 0 minute data, vitamin $\mathrm{C}$ and placebo days differ significantly when analyzed by linear regression (Figure 3 ). On the basis of the slopes, vitamin $\mathrm{C}$ decreased the postexercise $\mathrm{FEV}_{1}$ changes by $86 \%$ (95\% CI: $24 \%$ to $147 \%$ ), postexercise PEF changes by $74 \%$ (95\% CI: $31 \%$ to $118 \%$ ), and postexercise $\mathrm{FEF}_{60}$ changes by $90 \%$ (95\% CI: $9 \%$ to $171 \%)$. Postexercise $\mathrm{FEF}_{60}$ levels were also significantly influenced by vitamin $C(P=0.003)$. Thus, significant effects on postexercise pulmonary function changes by vitamin $C$ can also be seen immediately after the exercise challenge test. This analysis is shown in Additional file 2. 


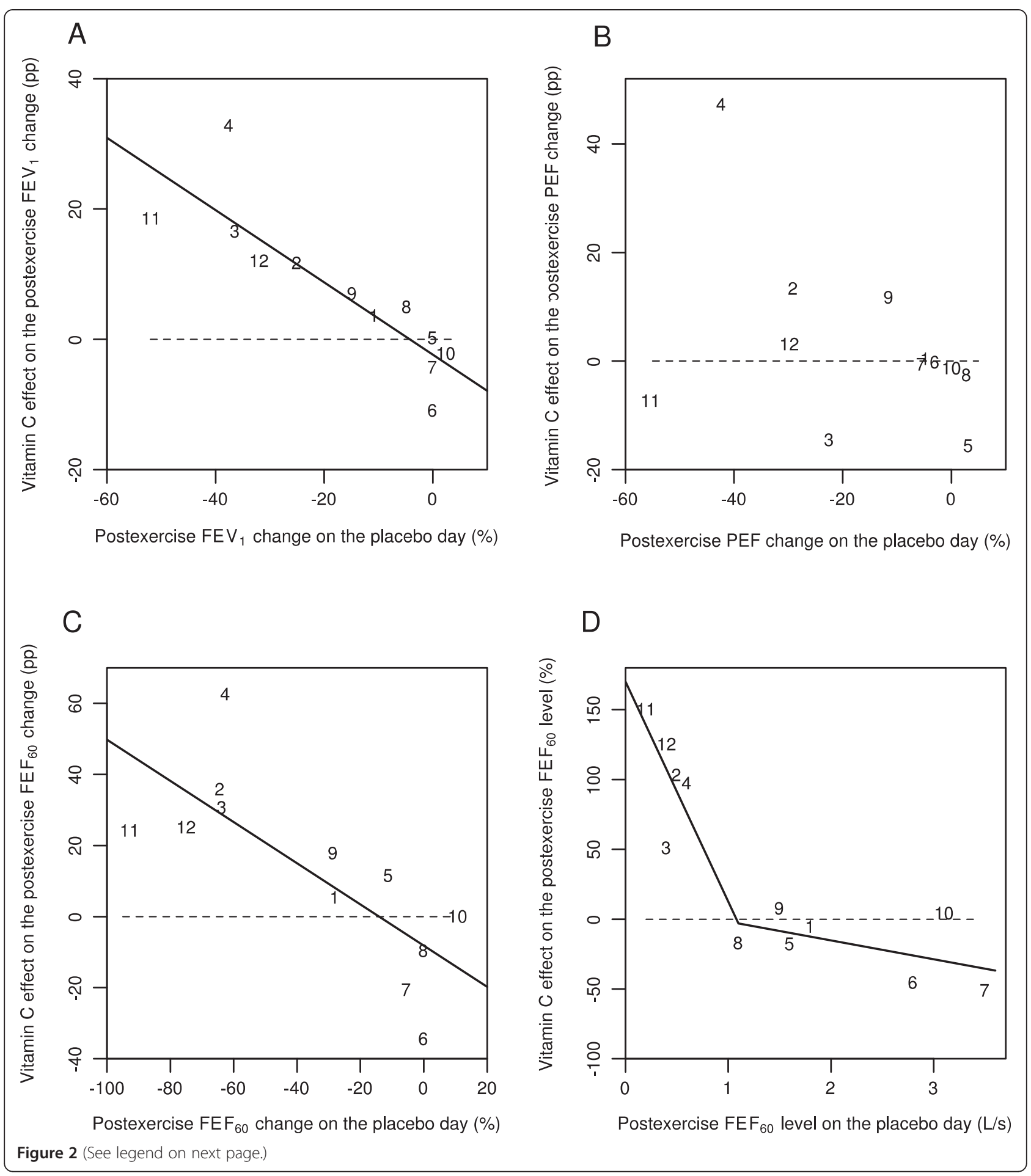


(See figure on previous page.)

Figure 2 Effect of vitamin C on 5-min postexercise changes for different pulmonary function outcomes according to the study by Schlesinger and Schachter [56]. Effect of vitamin C on the following 5 min after exercise: A) the postexercise FEV ${ }_{1}$ change, B) the postexercise $P E F$ change, $\mathbf{C}$ ) the postexercise $\mathrm{FEF}_{60}$ change, and $\mathbf{D}$ ) the postexercise $\mathrm{FEF}_{60}$ level. Figures $2 \mathrm{~A}, \mathrm{~B}$, and $\mathrm{C}$ show the effect of vitamin $\mathrm{C}$ in

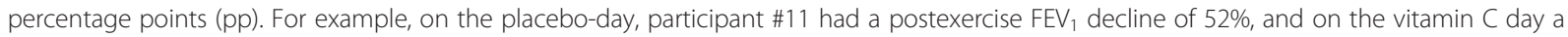
postexercise $\mathrm{FEV}_{1}$ decline of $33 \%$, which gives the $19 \mathrm{pp}$ improvement shown in Figure $2 \mathrm{~A}$. Figure 2D shows the effect of vitamin $\mathrm{C}$ in percentages. For example, on the placebo-day, participant \#11 had a postexercise $\mathrm{FEF}_{60}$ level of $0.2 \mathrm{~L} / \mathrm{s}$, and on the vitamin $\mathrm{C}$ day a postexercise $\mathrm{FEF}_{60}$ level of $0.5 \mathrm{~L} / \mathrm{s}$, which gives the $150 \%$ increase shown in Figure 2D. Figure 2 uses the same identification numbers for participants as those used in the original paper [56]. The dash lines indicate equality between vitamin C and placebo. If vitamin C had no effect, the observations would be located randomly and symmetrically around the dash lines. The continuous lines indicate the regression lines. In Figure $2 \mathrm{~A}$, the addition of the placebo-day postexercise $\mathrm{FEV}_{1}$ change to the model containing the intercept improved the model fit by $X^{2}(1 \mathrm{df})=16.5(\mathrm{P}=0.0001)$. In Figure 2B, the slope did not significantly differ from the null effect and therefore the regression line is not shown. In Figure $2 \mathrm{C}$, addition of the placebo-day postexercise $\mathrm{FEF}_{60}$ change to the model containing the intercept improved the model fit by $x^{2}(1 \mathrm{~d} f)=10.5(P=0.001)$. In Figure 2D, adding the two spline segments with the knot at $1.1 \mathrm{~L} / \mathrm{s}$ to the model containing only the intercept improved the model fit by $x^{2}(2 \mathrm{df})=24.7(P=0.000004)$.

For the statistical methods of Figure 2, see Additional file 1.

\section{Respiratory symptoms caused by exercise}

In evidence-based medicine (EBM) the primary focus of interest is on clinically relevant outcomes, including symptoms such as cough, sore throat and dyspnea. From the EBM perspective, laboratory outcomes such as $\mathrm{FEV}_{1}$ are surrogates and of secondary importance. Postexercise $\mathrm{FEV}_{1}$ decline and postexercise respiratory symptoms are poorly correlated $[4,6,7]$. Therefore, the effects of vitamin $\mathrm{C}$ administration on respiratory symptoms caused by exercise is an important question that should be concurrently considered along with its effects on the pulmonary function test values. None of the three trials on vitamin C and EIB recorded respiratory symptoms associated with the exercise tests (Table 1). Nevertheless, Tecklenburg et al. did report that asthma symptoms were less intense after the vitamin $\mathrm{C}$ administration period compared with the placebo period [51].

Five separate randomized placebo-controlled trials reported the effects of vitamin $\mathrm{C}$ on respiratory symptoms during and after heavy physical stress and, according to a meta-analysis, vitamin $\mathrm{C}$ administration decreased the incidence of respiratory symptoms in these studies by $52 \%$ (95\% CI: $36 \%$ to $65 \%$ ) [65,66]. Three of the studies were conducted on marathon runners [67-69], one study used Canadian soldiers on a winter exercise [70], and one study was on schoolchildren in a skiing camp in the Swiss Alps [71]. In the general population, acute cough and sore throat usually indicates a viral etiology, and authors of these five trials assumed that the respiratory symptoms were caused by viruses. However, when such symptoms occur after a marathon run and other endurance sports sessions, they are not always caused by a viral infection. Instead they can result from an injury to the airway epithelium caused by hours of exceptional ventilatory exertion [1-3,72]. Respiratory symptoms associated with physical irritation of the airways, allergy, and viral infections are all similar [66,73], and therefore there is no justification to assume that all the respiratory symptoms in the above-mentioned five studies were caused by viruses. In one study, $70 \%$ of respiratory symptom episodes of elite athletes were caused by a non-infectious etiology, which indicates high prevalence of respiratory symptoms not caused by viruses in athletes [74].

In their study on marathon runners, Peters et al. [67] recorded the "self-reported symptoms including a running nose, sneezing, sore throat, cough" during a 2-week period after the race [67]. The incidence of post-race cough was reduced by $71 \%$ in the vitamin $C$ group as compared to the placebo group $(\mathrm{P}[2-\mathrm{t}]=0.014 ; 4 / 43$ vs. $13 / 41)$. The incidence of sore throat was reduced by $67 \%$ in the vitamin $C$ group $(P=0.001 ; 8 / 43$ vs. $23 / 41)$. In contrast, vitamin $C$ had no significant effect on the incidence of runny nose ( $P=0.2 ; 13 / 43$ vs. $19 / 41)$, which is the most bothersome symptom of rhinovirus infections [75]. Peters et al. did not carry out any virologic or pulmonary function tests and therefore the etiology of the cough and sore throat in the marathon runners is uncertain [67]. It is plausible that the common cold studies on marathon runners may have been partly measuring the effect of vitamin $\mathrm{C}$ on the epithelial injury caused by the heavy exertional ventilation.

A recent randomized trial in Israel found that vitamin C shortened the duration of respiratory symptoms in male adolescent competitive swimmers by $47 \%$ (95\% CI: $14 \%$ to $80 \%$ ), but no effect was seen in their female counterparts [76]. The difference found between the sexes in that study was significant $(P=0.003)$. Here too, the etiology was not investigated and the respiratory symptoms might have been partly caused by the noninfectious irritation of swimmers' airways [77].

Thus, in six randomized trials vitamin $C$ reduced the incidence and duration of respiratory symptoms caused by heavy physical activity, yet it is not clear to what extent the symptoms were caused by non-infectious injury to the airway epithelium as opposed to viral infections. Irrespective of the etiology, symptoms are more important from the EBM point of view than laboratory measurements such as $\mathrm{FEV}_{1}$. 


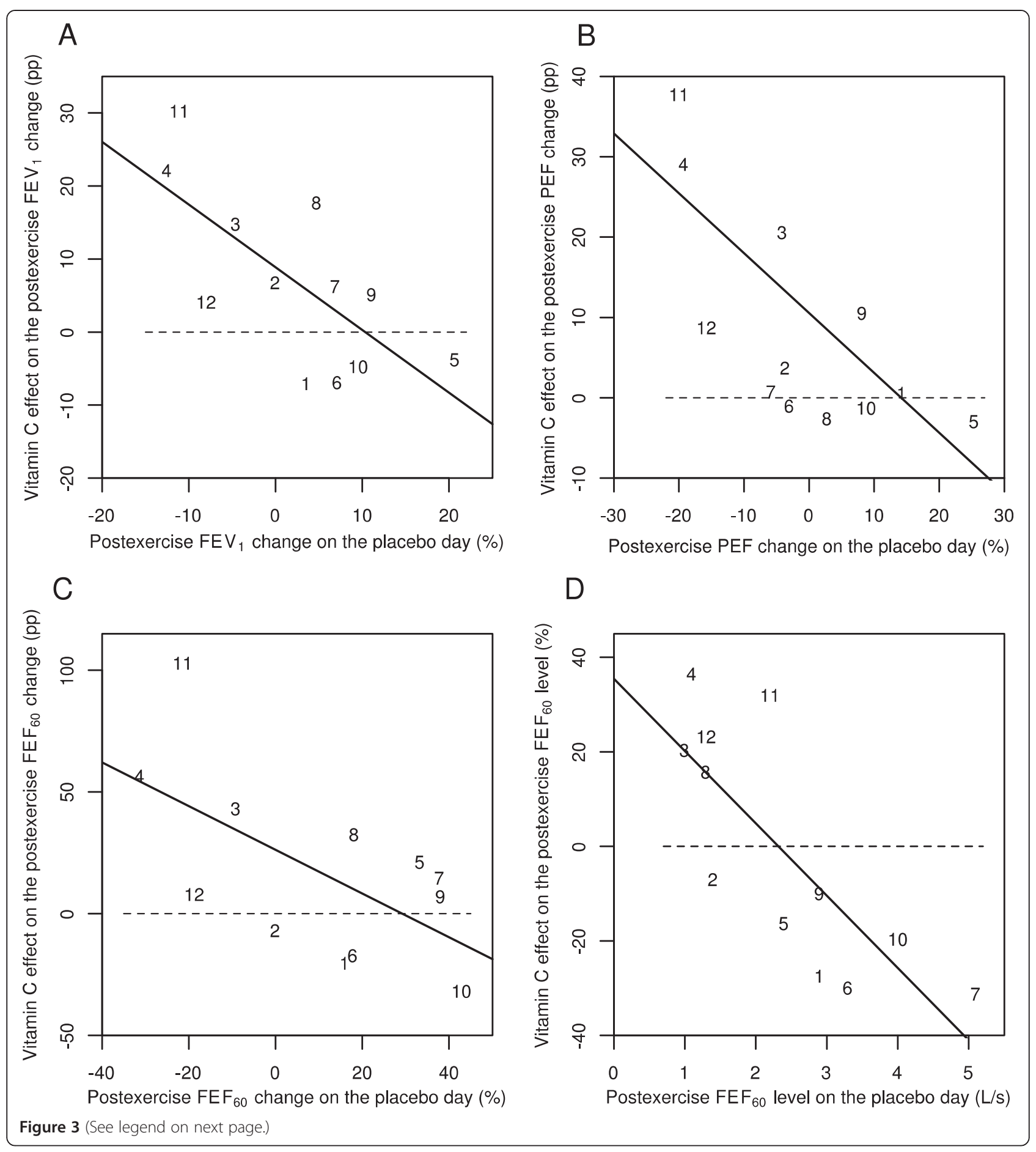




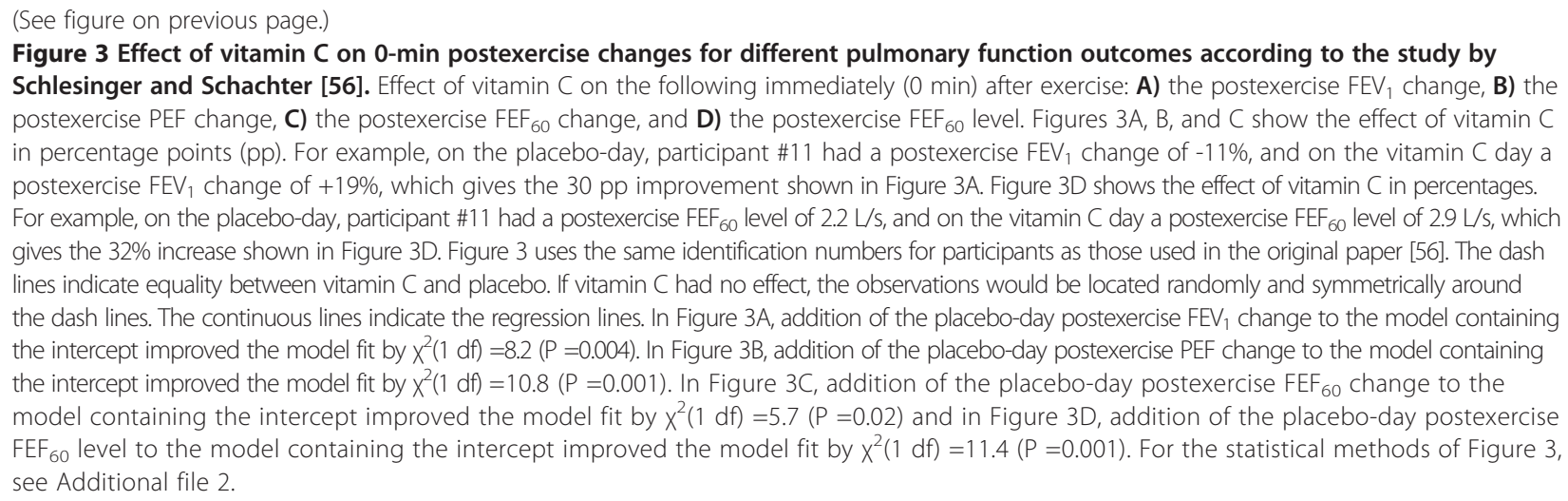

\section{Asthma phenotypes other than EIB}

Asthma is a heterogeneous syndrome, an "umbrella concept," that includes different phenotypes with different underlying pathophysiologies $[78,79]$. Therefore, it is relevant to consider whether the effects of vitamin $\mathrm{C}$ are limited to EIB or whether vitamin $\mathrm{C}$ might also influence other asthma phenotypes. There is evidence that some virus infections cause a transient increase in oxidative stress $[80,81]$, and a systematic review identified three studies that indicated that vitamin $\mathrm{C}$ might protect against common cold-induced asthma [82].

A 4-month trial on 154 British asthmatics showed that the $\mathrm{FEV}_{1}$ level was not influenced by $1 \mathrm{~g} /$ day of vitamin $\mathrm{C}$ [83]. Moreover, the $\mathrm{FEV}_{1}$ level was not influenced by a 5 -year administration of $0.25 \mathrm{~g} /$ day of vitamin $\mathrm{C}$ along with vitamin $E$ and $\beta$-carotene in a large-scale trial on 20,536 British adults [84]. These two British-based studies imply that vitamin $C$ supplementation does not influence pulmonary functions in patients with stable asthma or in relatively healthy people. Nevertheless, the study on British asthmatics found that the need for inhaled corticosteroids was lower in the vitamin $C$ group [85]. In any case, vitamin $\mathrm{C}$ may beneficially influence pulmonary functions of some people under certain forms of acute stress, such as when they endure heavy physical activity or suffer from a viral respiratory tract infection.

\section{Refocusing research onto the biological effects of vitamin C}

Vitamin $\mathrm{C}$ was identified in the search for the substance the deficiency of which led to scurvy. These early studies led to the assumption that the sole physiological function of vitamin $\mathrm{C}$ is just to prevent and treat scurvy. Therefore, it is often assumed that higher doses of vitamin $C$ have no benefit when a person does not suffer from scurvy. In view of this strongly entrenched assumption, assessing the role of vitamin $C$ on diseases and conditions other than scurvy is not just an empirical question but also a conceptual issue.
Bias against vitamin supplementation in general has been well documented [86-88]. Several influential reviews on vitamin $\mathrm{C}$ and the common cold have been shown to be erroneous and misleading [89,90]. A Cochrane review on vitamin $C$ and asthma [91] was shown to have substantial errors in the extraction of data and data analysis, and the review misled readers for a decade [92,93]. If we wish for progress in the understanding of the effects of vitamin $\mathrm{C}$ on EIB, it needs to be acknowledged that the effects of vitamin $C$ are not limited to the prevention of scurvy alone and, consequently, the published data on vitamin $\mathrm{C}$ should be analyzed carefully and comprehensively.

\section{Conclusions}

Three trials have examined the effect of vitamin $\mathrm{C}$ on EIB and found that 0.5 to $2 \mathrm{~g}$ /day vitamin $C$ halved the postexercise $\mathrm{FEV}_{1}$ decline (Figure 1). In addition, five trials found that vitamin $\mathrm{C}$ administration halved the incidence of respiratory symptoms after short-term heavy physical stress $[65,66]$ and one other trial found that vitamin $\mathrm{C}$ administration halved the duration of the respiratory symptoms in male adolescent competitive swimmers [76]. Although these nine randomized trials indicate that vitamin $\mathrm{C}$ has genuine biological effects on pulmonary functions and respiratory symptoms in people doing heavy exercise, it is unclear how the effect of vitamin $C$ depends on the kind of physical activity, the level of physical activity, the temperature of ambient air, the humidity of ambient air, the dose of vitamin $C$, the level of dietary intake of vitamin $C$, and various other factors.

Given the safety and low cost of vitamin $C$, and the consistency of positive findings in the nine randomized trials on vitamin $\mathrm{C}$ against EIB and respiratory symptoms, it seems reasonable for physically active people to test whether vitamin $\mathrm{C}$ is beneficial on an individual basis, if they have documented EIB or suffer from respiratory symptoms such as cough or sore throat after taking vigorous exercise. 
In future studies on vitamin $\mathrm{C}$ and EIB, a variety of pulmonary function outcomes should be measured. Although $\mathrm{FEV}_{1}$ is currently the standard measure for diagnosing $\mathrm{EIB}$, the effect of vitamin $\mathrm{C}$ on the postexercise $\mathrm{FEF}_{50}$ and $\mathrm{FEF}_{75}$ levels should also be examined, as they may provide important additional information (Figures 2D and 3D). Furthermore, PEF is much easier to measure than carrying out a spirometry test. Therefore the possibility that the postexercise PEF decline might identify those people who may benefit from vitamin $C$ administration should be investigated (Figures $2 \mathrm{~B}$ and $3 \mathrm{~B}$ ).

In the earlier studies on vitamin $C$ and EIB, only the mean effects on $\mathrm{FEV}_{1}$ were calculated $[51,56]$ or EIB was dichotomized by an arbitrary cut off level [57]. However, postexercise $\mathrm{FEV}_{1}$ decline is a continuous variable and the effect of vitamin $C$ may depend on the baseline level of pulmonary function decline. Therefore, linear modelling is a much more informative way to analyze vitamin $\mathrm{C}$ effects on pulmonary functions and it should be used in the future studies (Figures 2 and 3). Finally, while pulmonary function tests are objective outcomes, symptoms are much more relevant outcomes from the EBM point of view, therefore both of them should be recorded concurrently in future investigations.

\section{Additional files}

Additional file 1: Methods for Figure 2 (5 min data ) and Figures $2 \mathrm{E}$ and $2 \mathrm{~F}$.

Additional file 2: Methods for Figure 3 ( $0 \mathrm{~min}$ data) and Figures $3 \mathrm{E}$ and $3 \mathrm{~F}$.

\section{Abbreviations}

Cl: Confidence interval; EBM: Evidence based medicine; EIB: Exercise-induced bronchoconstriction; $\mathrm{FEF}_{25-75}$ : Mean forced expiratory flow between $25 \%$ and $75 \%$ of $\mathrm{FVC}_{\text {; }} \mathrm{FEF}_{50}$ : Forced expiratory flow when $50 \%$ of the FVC has been expired; $\mathrm{FEF}_{60}$ : Forced expiratory flow when $60 \%$ of the FVC has been expired; $\mathrm{FEF}_{60(\mathrm{p})}$ : $\mathrm{FEF}_{60}$ value based on partial flow volume curves; $\mathrm{FEF}_{75}$ : Forced expiratory flow when $75 \%$ of the FVC has been expired; $F_{E V}$ : Forced expiratory volume in 1 second; FVC: Forced vital capacity; LT: Leukotriene; PEF: Peak expiratory flow; PG: Prostaglandin.

\section{Competing interests}

This research received no specific grant from any funding agency in the public, commercial or not-for-profit sectors. The author declares that he has no competing interests.

Received: 1 May 2014 Accepted: 1 November 2014 Published: 27 November 2014

\section{References}

1. Anderson SD, Kippelen P: Airway injury as a mechanism for exerciseinduced bronchoconstriction in elite athletes. J Allergy Clin Immunol 2008, 122:225-235. http://www.ncbi.nlm.nih.gov/pubmed/18554705. http://dx.doi. org/10.1016/j.jaci.2008.05.001.

2. Weiler JM, Anderson SD, Randolph C: Pathogenesis, prevalence, diagnosis, and management of exercise-induced bronchoconstriction. Ann Allergy Asthma Immunol 2010, 105(6):S1-S47. http://dx.doi.org/10.1016/j. anai.2010.09.021.

3. Parsons JP, Hallstrand TS, Mastronarde JG, Kaminsky DA, Rundell KW, Hull JH, Storms WW, Weiler JM, Cheek FM, Wilson KC, Anderson SD: An official
American thoracic society clinical practice guideline: exerciseinduced bronchoconstriction. Am J Respir Crit Care Med 2013, 187:1016-1027. http://www.ncbi.nlm.nih.gov/pubmed/23634861. http://dx.doi.org/10.1164/ rccm.201303-0437ST.

4. De Baets F, Bodart E, Dramaix-Wilmet M, Van Daele S, de Bilderling G, Masset $S$, Vermeire $P$, Michel $O$ : Exercise-induced respiratory symptoms are poor predictors of bronchoconstriction. Pediatr Pulmonol 2005, 39:301-305. http://www.ncbi.nlm.nih.gov/pubmed/15678500. http://dx. doi.org/10.1002/ppul.20185.

5. Thomas S, Wolfarth B, Wittmer C, Nowak D, Radon K, GA2LEN-Olympic study-Team: Self-reported asthma and allergies in top athletes compared to the general population - results of the German part of the GA2LENOlympic study 2008. Allergy Asthma Clin Immunol 2010, 6:31. http://dx.doi. org/10.1186/1710-1492-6-31.

6. Rundell KW, Wilber RL, Szmedra L, Jenkinson DM, Mayers LB, Im J: Exerciseinduced asthma screening of elite athletes: field versus laboratory exercise challenge. Med Sci Sports Exerc 2000, 32:309-316. http://www.ncbi. nlm.nih.gov/pubmed/10694112. http://dx.doi.org/10.1097/00005768200002000-00010.

7. Rundell KW, Im J, Mayers LB, Wilber RL, Szmedra L, Schmitz HR: Self-reported symptoms and exercise-induced asthma in the elite athlete. Med Sci Sports Exerc 2001, 33:208-213. http://www.ncbi.nlm.nih.gov/pubmed/11224807. http://dx.doi.org/10.1097/00005768-200102000-00006.

8. Hallstrand TS, Moody MW, Wurfel MM, Schwartz LB, Henderson WR, Aitken ML: Inflammatory basis of exercise-induced bronchoconstriction. Am J Respir Crit Care Med 2005, 172:679-686. http://www.ncbi.nlm.nih.gov/pubmed/15947280. http://dx.doi.org/10.1164/rccm.200412-16670C.

9. Shin HW, Schwindt CD, Aledia AS, Rose-Gottron CM, Larson JK, Newcomb RL, Cooper DM, George SC: Exercise-induced bronchoconstriction alters airway nitric oxide exchange in a pattern distinct from spirometry. Am J Physiol Regul Integr Comp Physiol 2006, 291:R1741-R1748. http://www.ncbi.nlm.nih. gov/pubmed/16840654. http://dx.doi.org/10.1152/ajpregu.00178.2006.

10. Chinellato I, Piazza M, Peroni D, Sandri M, Chiorazzo F, Boner AL, Piacentini G: Bronchial and alveolar nitric oxide in exercise-induced bronchoconstriction in asthmatic children. Clin Exp Allergy 2012, 42:1190-1196. http://www.ncbi.nlm. nih.gov/pubmed/22805466. http://dx.doi.org/10.1111/j.1365-2222.2012.03973.x.

11. Baumann JM, Rundell KW, Evans TM, Levine AM: Effects of cysteine donor supplementation on exercise-induced bronchoconstriction. Med Sci Sports Exerc 2005, 37:1468-1473. http://www.ncbi.nlm.nih.gov/pubmed/ 16177596. http://dx.doi.org/10.1249/01.mss.0000177479.57468.15.

12. Barreto M, Villa MP, Olita C, Martella S, Ciabattoni G, Montuschi P: 8-Isoprostane in exhaled breath condensate and exercise-induced bronchoconstriction in asthmatic children and adolescents. Chest 2009, 135:66-73. http://dx.doi.org/ 10.1378/chest.08-0722.

13. Powers SK, Nelson WB, Hudson MB: Exercise-induced oxidative stress in humans: cause and consequences. Free Radic Biol Med 2011, 51:942-950. http://www.ncbi.nlm.nih.gov/pubmed/21167935. http://dx.doi.org/10.1016/j. freeradbiomed.2010.12.009

14. Ashton $T$, Young IS, Peters JR, Jones E, Jackson SK, Davies B, Rowlands CC: Electron spin resonance spectroscopy, exercise, and oxidative stress: an ascorbic acid intervention study. J Appl Physiol 1999, 87:2032-2036. http://www.ncbi.nlm.nih.gov/pubmed/10601146

15. Davison GW, Ashton T, Davies B, Bailey DM: In vitro electron paramagnetic resonance characterization of free radicals: relevance to exercise-induced lipid peroxidation and implications of ascorbate prophylaxis. Free Radic Res 2008, 42:379-386. http://dx.doi.org/10.1080/10715760801976618.

16. Sánchez-Quesada JL, Jorba O, Payés A, Otal C, Serra-Grima R, González-Sastre F, Ordóñez-Llanos J: Ascorbic acid inhibits the increase in low-density lipoprotein (LDL) susceptibility to oxidation and the proportion of electronegative LDL induced by intense aerobic exercise. Coron Artery Dis 1998, 9:249-255. http://www.ncbi.nlm.nih.gov/pubmed/9710684. http://dx.doi.org/10.1097/00019501-199809050-00002.

17. Silvestro A, Scopacasa F, Oliva G, de Cristofaro T, Iuliano L, Brevetti G: Vitamin C prevents endothelial dysfunction induced by acute exercise in patients with intermittent claudication. Atherosclerosis 2002, 165:277-283. http://www.ncbi.nlm.nih.gov/pubmed/12417278. http://dx.doi.org/10.1016/ S0021-9150(02)00235-6.

18. Goldfarb AH, Patrick SW, Bryer S, You T: Vitamin C supplementation affects oxidative-stress blood markers in response to a 30-minute run at 75\% VO2max. Int I Sport Nutr Exerc Metab 2005, 15:279-290. http://www.ncbi. nlm.nih.gov/pubmed/16131698 
19. Shanklin DR, O'Dell TE: Ascorbic acid and the lung. Nature 1966, 210:1329-1331. http://dx.doi.org/10.1038/2101329a0.

20. Castranova V, Wright JR, Colby HD, Miles PR: Ascorbate uptake by isolated rat alveolar macrophages and type II cells. J Applied Physiol 1983, 54:208-214. http://www.ncbi.nlm.nih.gov/pubmed/6826406.

21. Skoza L, Snyder A, Kikkawa Y: Ascorbic acid in bronchoalveolar wash. Lung 1983, 161:99-109. http://www.ncbi.nlm.nih.gov/pubmed/6221162. http://dx.doi.org/10.1007/BF02713848.

22. Slade R, Crissman K, Norwood J, Hatch G: Comparison of antioxidant substances in bronchoalveolar lavage cells and fluid from humans, guinea pigs, and rats. Exp Lung Res 1993, 19:469-484. http://www.ncbi.nlm. nih.gov/pubmed/8370346. http://dx.doi.org/10.3109/01902149309064358.

23. Wiester MJ, Tepper JS, Winsett DW, Crissman KM, Richards JH, Costa DL: Adaptation to ozone in rats and its association with ascorbic acid in the lung. Fundam App/ Toxicol 1996, 31:56-64. http://www.ncbi.nlm.nih.gov/ pubmed/8998953. http://dx.doi.org/10.1006/faat.1996.0075.

24. Wiester MJ, Winsett DW, Richards JH, Jackson MC, Crissman KM, Costa DL. Ozone adaptation in mice and its association with ascorbic acid in the lung. Inhal Toxicol 2000, 12:577-590. http://www.ncbi.nlm.nih.gov/pubmed/ 10880145. http://informahealthcare.com/doi/abs/10.1080/08958370050030958.

25. Arad ID, Forman $H J$, Fisher AB: Ascorbate efflux from guinea pig and rat lungs: effect of starvation and O2 exposure. J Lab Clin Med 1980, 96:673-681. http://www.ncbi.nlm.nih.gov/pubmed/6252268.

26. Leung HW, Morrow PE: Interaction of glutathione and ascorbic acid in guinea pig lungs exposed to nitrogen dioxide. Res Commun Chem Pathol Pharmacol 1981, 31:111-118. http://www.ncbi.nlm.nih.gov/ pubmed/7255866.

27. Matzen RN: Effect of vitamin C and hydrocortisone on the pulmonary edema produced by ozone in mice. J Appl Physiol 1957, 11:105-109. http://www.ncbi.nlm.nih.gov/pubmed/13462928.

28. Mittler S: Protection against death due to ozone poisoning. Nature 1958, 181:1063-1064. http://www.ncbi.nlm.nih.gov/pubmed/13541362. http://dx doi.org/10.1038/1811063a0

29. Brown LA, Harris FL, Jones DP: Ascorbate deficiency and oxidative stress in the alveolar type II cell. Am J Physiol 1997, 273:L782-L788. http://www. ncbi.nlm.nih.gov/pubmed/9357853. http://ajplung.physiology.org/content/ 273/4/L782

30. Mudway IS, Stenfors N, Blomberg A, Helleday R, Dunster C, Marklund SL, Frew AJ, Sandström T, Kelly FJ: Differences in basal airway antioxidant concentrations are not predictive of individual responsiveness to ozone. Free Radic Biol Med 2001, 31:962-974. http://www.ncbi.nlm.nih.gov/pubmed/11595381. http://dx.doi.org/ 10.1016/S0891-5849(01)00671-2

31. Glick D, Hosoda S: Ascorbic acid in normal mast cells and macrophages and in neoplastic mast cells. Proc Soc Exp Biol Med 1965, 119:52-56. http://www.ncbi.nlm.nih.gov/pubmed/14297882

32. Ortner MJ: The oxidation of endogenous ascorbic acid during histamine secretion by rat peritoneal mast cells. Exp Cell Res 1980, 129:485-487. http://dx.doi.org/10.1016/0014-4827(80)90521-2.

33. Dawson W, West GB: The influence of ascorbic acid on histamine metabolism in guinea-pigs. Br J Pharmacol 1965, 24:725-734. http://dx.doi. org/10.1111/j.1476-5381.1965.tb01628.x.

34. Chatterjee IB, Gupta SD, Majumder AK, Nandi BK, Subramanian N: Effect of ascorbic acid on histamine metabolism in scorbutic guinea-pigs. J Physiol 1975, 251:271-279. http://www.ncbi.nlm.nih.gov/pubmed/52707. http://www. ncbi.nlm.nih.gov/pmc/articles/PMC1348426.

35. Johnston CS, Huang SN: Effect of ascorbic acid nutriture on blood histamine and neutrophil chemotaxis in guinea pigs. J Nutr 1991, 121:126-130. http://jn.nutrition.org/content/121/1/126.

36. Nandi BK, Subramanian N, Majumder AK, Chatterjee IB: Effect of ascorbic acid on detoxification of histamine under stress conditions. Biochem Pharmacol 1974, 23:643-647. http://www.ncbi.nlm.nih.gov/pubmed/4132605. http://dx. doi.org/10.1016/0006-2952(74)90629-7.

37. Clemetson CA: Histamine and ascorbic acid in human blood. J Nutr 1980, 110:662-668. http://www.ncbi.nlm.nih.gov/pubmed/7365537. http://jn.nutrition.org/content/110/4/662.

38. Johnston CS, Retrum KR, Srilakshmi JC: Antihistamine effects and complications of supplemental vitamin C. J Am Diet Assoc 1992, 92:988-989. http://www.ncbi.nlm.nih.gov/pubmed/1640045.

39. Johnston CS, Solomon RE, Corte C: Vitamin C depletion is associated with alterations in blood histamine and plasma free carnitine in adults. J Am
Coll Nutr 1996, 15:586-591. http://www.ncbi.nlm.nih.gov/pubmed/8951736. http://dx.doi.org/10.1080/07315724.1996.10718634.

40. Hagel AF, Layritz CM, Hagel WH, Hagel HJ, Hagel E, Dauth W, Kressel J, Regnet T, Rosenberg A, Neurath MF, Molderings GJ, Raithel M: Intravenous infusion of ascorbic acid decreases serum histamine concentrations in patients with allergic and non-allergic diseases. Naunyn Schmiedebergs Arch Pharmacol 2013, 386:789-793. http://dx.doi.org/10.1007/s00210-0130880-1. http://www.ncbi.nlm.nih.gov/pubmed/23666445.

41. Guirgis HM: The regulatory role of vitamin $C$ on the adrenal function and resistance to histamine aerosol in the scorbutic guinea-pig. J Pharm Pharmacol 1965, 17:674-675. http://dx.doi.org/10.1111/j.2042-7158.1965. tb07586.x.

42. Dawson W, Hemsworth BA, Stockham MA: Actions of sodium ascorbate on smooth muscle. Br J Pharmacol Chemother 1967, 31:269-275. http://dx doi.org/10.1111/j.1476-5381.1967.tb01997.x.

43. Brink C, Ridgway P, Douglas JS: Regulation of guinea pig airways in vivo by endogenous prostaglandins. Pol J Pharmacol Pharm 1978, 30:157-166. http://www.ncbi.nlm.nih.gov/pubmed/673926.

44. Mohsenin V, Tremml PG, Rothberg KG, Souhrada M, Douglas JS: Airway responsiveness and prostaglandin generation in scorbutic guinea pigs. Prostaglandins Leukot Essent Fatty Acids 1988, 33:149-155. http://www.ncbi.nlm.nih.gov/pubmed/3186781.

45. Zuskin E, Lewis AJ, Bouhuys A: Inhibition of histamine-induced airway constriction by ascorbic acid. J Allergy Clin Immunol 1973, 51:218-226. http://dx.doi.org/10.1016/0091-6749(73)90141-3.

46. Sipahi E, Ercan ZS: The mechanism of the relaxing effect of ascorbic acid in guinea pig isolated tracheal muscle. Gen Pharmacol 1997, 28:757-760. http://dx.doi.org/10.1016/S0306-3623(96)00277-7.

47. Yeadon M, Wilkinson D, Darley-Usmar V, O'Leary VJ, Payne AN: Mechanisms contributing to ozone-induced bronchial hyperreactivity in guinea-pigs. Pulm Pharmacol 1992, 5:39-50. http://dx.doi.org/10.1016/0952-0600(92) 90016-A.

48. Puglisi L, Berti F, Bosisio E, Longiave D, Nicosia S: Ascorbic acid and PGF2a antagonism on tracheal smooth muscle. Adv Prostaglandin Tromboxane Res 1976, 1:503-506. http://www.ncbi.nlm.nih.gov/pubmed/998441.

49. Rothberg KG, Hitchcock M: Effects of ascorbic acid deficiency on the in vitro biosynthesis of cyclooxygenase metabolites in guinea pig lungs. Prostaglandins Leukot Med 1983, 12:137-147. http://dx.doi.org/10.1016/02621746(83)90077-X

50. Ogilvy CS, DuBois AB, Douglas JS: Effects of ascorbic acid and indomethacin on the airways of healthy male subjects with and without induced bronchoconstriction. J Allergy Clin Immunol 1981, 67:363-369. http://dx.doi.org/10.1016/0091-6749(81)90081-6.

51. Tecklenburg SL, Mickleborough TD, Fly AD, Bai Y, Stager JM: Ascorbic acid supplementation attenuates exercise-induced bronchoconstriction in patients with asthma. Respir Med 2007, 101:1770-1778. http://www. ncbi.nlm.nih.gov/pubmed/17412579. http://dx.doi.org/10.1016/j. rmed.2007.02.014.

52. Schock BC, Koostra J, Kwack S, Hackman RM, Van Der Vliet A, Cross CE: Ascorbic acid in nasal and tracheobronchial airway lining fluids. Free Radic Biol Med 2004, 37:1393-1401. http://www.ncbi.nlm.nih.gov/pubmed/ 15454278. http://dx.doi.org/10.1016/j.freeradbiomed.2004.07.023.

53. Behndig AF, Blomberg A, Helleday R, Kelly FJ, Mudway IS: Augmentation of respiratory tract lining fluid ascorbate concentrations through supplementation with vitamin C. Inhal Toxicol 2009, 21:250-258. http://dx.doi.org/ 10.1080/08958370802474736.

54. Hemilä H: Vitamin C may alleviate exercise-induced bronchoconstriction: a meta-analysis. BMJ Open 2013, 3:e002416. http://dx.doi.org/10.1136/ bmjopen-2012-002416

55. Hemilä H: Vitamin C should be tested against exercise-induced bronchoconstriction. Am J Respir Crit Care Med 2013, 188:1370. http://dx.doi. org/10.1164/rccm.201307-1205LE.

56. Schachter EN, Schlesinger A: The attenuation of exercise-induced bronchospasm by ascorbic acid. Ann Allergy 1982, 49:146-151. http://www. ncbi.nlm.nih.gov/pubmed/7114587.

57. Cohen HA, Neuman I, Nahum H: Blocking effect of vitamin C in exerciseinduced asthma. Arch Pediatr Adolescent Med 1997, 151:367-370. http://dx doi.org/10.1001/archpedi.1997.02170410041005.

58. Murphy JD, Ferguson CS, Brown KR, Harms CA: The effect of dietary antioxidants on lung function in exercise induced asthma [abstract]. Med Sci Sports Exerc 2002, 34(5):S155. 
59. MCFadden ER Jr: Resurrection men and the FEF25-75. J Allergy Clin Immunol 2010, 126:535-536. http://dx.doi.org/10.1016/j.jaci.2010.06.035.

60. Simon MR, Chinchilli VM, Phillips BR, Sorkness CA, Lemanske RF Jr, Szefler SJ, Taussig L, Bacharier LB, Morgan W: Forced expiratory flow between $25 \%$ and $75 \%$ of vital capacity and FEV1/forced vital capacity ratio in relation to clinical and physiological parameters in asthmatic children with normal FEV1 values. J Allergy Clin Immunol 2010, 126:527-534. http://www. ncbi.nlm.nih.gov/pubmed/20638110. http://dx.doi.org/10.1016/j. jaci.2010.05.016.

61. Haas F, Axen K, Schicchi JS: Use of maximum expiratory flow-volume curve parameters in the assessment of exercise-induced bronchospasm. Chest 1993, 103:64-68. http://www.ncbi.nlm.nih.gov/pubmed/8417938. http://dx.doi.org/10.1378/chest.103.1.64.

62. Custovic A, Arifhodzic N, Robinson A, Woodcock A: Exercise testing revisited. The response to exercise in normal and atopic children. Chest 1994, 105:1127-1132. http://www.ncbi.nlm.nih.gov/pubmed/8162737. http://dx.doi.org/10.1378/chest.105.4.1127.

63. Fonseca-Guedes $\mathrm{CH}$, Cabral AL, Martins MA: Exercise-induced bronchospasm in children: comparison of FEV1 and FEF $25-75 \%$ responses. Pediatr Pulmonol 2003, 36:49-54. http://www.ncbi.nlm.nih.gov/pubmed/12772223. http://dx.doi. org/10.1002/ppul.10309

64. Bar-Yishay E, Amirav I, Goldberg S: Comparison of maximal midexpiratory flow rate and forced expiratory flow at $50 \%$ of vital capacity in children. Chest 2003, 123:731-735. http://www.ncbi.nlm.nih.gov/pubmed/12628870. http://dx.doi.org/10.1378/chest.123.3.731

65. Hemilä H: Vitamin C and common cold incidence: a review of studies with subjects under heavy physical stress. Int I Sports Med 1996, 17:379-383. http://dx.doi.org/10.1055/s-2007-972864. Available at: http://hdl.handle.net/ 10250/7983

66. Hemilä H, Chalker E: Vitamin C for preventing and treating the common cold. Cochrane Database Syst Rev 2013, 1:CD000980. http://dx.doi.org/ 10.1002/14651858.CD000980.pub4.

67. Peters EM, Goetzsche JM, Grobbelaar B, Noakes TD: Vitamin C supplementation reduces the incidence of postrace symptoms of upperrespiratory-tract infection in ultramarathon runners. Am J Clin Nutr 1993, 57:170-174. http://www.ncbi.nlm.nih.gov/pubmed/8185726. http://ajcn. nutrition.org/content/57/2/170

68. Peters EM, Goetzsche JM, Joseph LE, Noakes TD: Vitamin C as effective as combinations of anti-oxidant nutrients in reducing symptoms of upper respiratory tract infection in ultramarathon runners. S Afr J Sports Med 1996, 11:23-27.

69. Moolla ME: The Effect of Supplemental Anti-Oxidants on the Incidence and Severity of Upper Respiratory Tract Infections in UItra-Marathon Runners, MSc Thesis. South Africa: University of Cape Town; 1996.

70. Sabiston BH, Radomski MW: Health Problems and Vitamin C in Canadian Northern Military Operations. DCIEM Report no. 74-R-1012. Downsview, Ontario, Canada: Defence and Civil Institute of Environmental Medicine; 1974:1-10. Available at: http://www.mv.helsinki.fi/home/hemila/CC/ Sabiston_1974_ch.pdf (accessed 18 Nov 2014).

71. Ritzel G: Critical analysis of the role of vitamin C in the treatment of the common cold [in German]. Helv Med Acta 1961, 28:63-68. Translation at: http://www.mv.helsinkifi/home/hemila/T3.pdf (accessed 18 Nov 2014).

72. Kippelen $\mathrm{P}$, Anderson SD: Airway injury during high-level exercise. $\mathrm{Br} J$ Sports Med 2012, 46:385-390. http://dx.doi.org/10.1136/bjsports-2011-090819.

73. Eccles R: Is the common cold a clinical entity or a cultural concept? Rhinology 2013, 51:3-8. http://www.ncbi.nlm.nih.gov/pubmed/23441305.

74. Spence L, Brown WJ, Pyne DB, Nissen MD, Sloots TP, McCormack JG, Locke AS, Fricker PA: Incidence, etiology, and symptomatology of upper respiratory illness in elite athletes. Med Sci Sports Exerc 2007, 39:577-586. http://www. ncbi.nlm.nih.gov/pubmed/17414793. http://dx.doi.org/10.1249/ mss.0b013e31802e851a.

75. Arruda E, Pitkäranta A, Witek TJ, Doyle CA, Hayden FG: Frequency and natural history of rhinovirus infections in adults during autumn. J Clin Microbiol 1997, 35:2864-2868. http://www.ncbi.nlm.nih.gov/pubmed/ 9350748. http://jcm.asm.org/content/35/11/2864

76. Constantini NW, Dubnov-Raz G, Eyal BB, Berry EM, Cohen AH, Hemilä H: The effect of vitamin $C$ on upper respiratory infections in adolescent swimmers: a randomized trial. Eur J Pediatr 2011, 170:59-63. http://www.ncbi.nlm.nih. gov/pubmed/20689965. http://dx.doi.org/10.1007/s00431-010-1270-z.

77. Bougault V, Boulet LP: Airway dysfunction in swimmers. Br J Sports Med 2012, 46:402-406. http://dx.doi.org/10.1136/bjsports-2011-090821.
78. Wenzel SE: Asthma: defining of the persistent adult phenotypes. Lancet 2006, 368:804-813. http://www.ncbi.nlm.nih.gov/pubmed/ 16935691. http://dx.doi.org/10.1016/50140-6736(06)69290-8.

79. Lötvall J, Akdis CA, Bacharier LB, Bjermer L, Casale TB, Custovic A, Lemanske RF Jr, Wardlaw AJ, Wenzel SE, Greenberger PA: Asthma endotypes: a new approach to classification of disease entities within the asthma syndrome. J Allergy Clin Immunol 2011, 127:355-360. http://dx.doi.org/10.1016/j.jaci.2010.11.037.

80. Akaike T: Role of free radicals in viral pathogenesis and mutation. Rev Med Virol 2001, 11:87-101. http://dx.doi.org/10.1002/rmv.303.

81. Castro SM, Guerrero-Plata A, Suarez-Real G, Adegboyega PA, Colasurdo GN, Khan AM, Garofalo RP, Casola A: Antioxidant treatment ameliorates respiratory syncytial virus-induced disease and lung inflammation. Am J Respir Crit Care Med 2006, 174:1361-1369. http://www.ncbi.n/m.nih.gov/pubmed/17008643. http://dx.doi.org/10.1164/rccm.200603-3190C.

82. Hemilä H: Vitamin $\mathrm{C}$ and common cold-induced asthma: a systematic review and statistical analysis. Allergy Asthma Clin Immunol 2013, 9:46. http://dx.doi.org/10.1186/1710-1492-9-46.

83. Fogarty A, Lewis SA, Scrivener SL, Antoniak M, Pacey S, Pringle M, Britton J: Oral magnesium and vitamin $C$ supplements in asthma: a parallel group randomized placebo-controlled trial. Clin Exp Allergy 2003, 33:1355-1359. http://www.ncbi.nlm.nih.gov/pubmed/14519140. http://dx.doi.org/10.1046/ j.1365-2222.2003.01777.x.

84. Heart Protection Study Collaborative Group: MRC/BHF heart protection study of antioxidant vitamin supplementation in 20,536 high-risk individuals: a randomised placebo-controlled trial. Lancet 2002, 360:23-33. http://www.ncbi.nlm.nih.gov/pubmed/12114037. http://dx.doi.org/10.1016/ S0140-6736(02)09328-5.

85. Fogarty A, Lewis SA, Scrivener SL, Antoniak M, Pacey S, Pringle M, Britton J: Corticosteroid sparing effects of vitamin $C$ and magnesium in asthma: a randomised trial. Respir Med 2006, 100:174-179. http://www.ncbi.nlm.nih. gov/pubmed/16338599. http://dx.doi.org/10.1016/j.rmed.2005.03.038

86. Goodwin JS, Tangum MR: Battling quackery: attitudes about micronutrient supplements in American Academic medicine. Arch Intern Med 1998, 158:2187-2191. http://dx.doi.org/10.1001/archinte.158.20.2187

87. Richards E: The politics of therapeutic evaluation: the vitamin C and cancer controversy. Soc Stud Sci 1988, 18:653-701. http://dx.doi.org/ 10.1177/030631288018004004

88. Louhiala P, Hemilä H: Can CAM treatments be evidence-based? Focus Altern Complement Ther 2014, 19:84-89. http://dx.doi.org/10.1111/fct.12110.

89. Hemilä H, Herman ZS: Vitamin C and the common cold: a retrospective analysis of Chalmers' review. J Am Coll Nutr 1995, 4:116-123. http://dx.doi. org/10.1080/07315724.1995.10718483. Available at: http://hdl.handle.net/ $10138 / 42358$.

90. Hemilä H: Vitamin C supplementation and common cold symptoms: problems with inaccurate reviews. Nutrition 1996, 12:804-809. http://dx. doi.org/10.1016/\$0899-9007(96)00223-7. Available at: http://hdl.handle.net/ 10250/7979.

91. Kaur B, Rowe BH, Arnold E: Vitamin C supplementation for asthma. Cochrane Database Syst Rev 2009, 1:CD000993. http://dx.doi.org/10.1002/ 14651858.CD000993.pub3.

92. Hemilä H: Feedback to Cochrane review on vitamin C and asthma. 2009, http://hdl.handle.net/10138/38500.

93. Hemilä H: Vitamin C and exercise-induced bronchoconstriction: further problems in the Cochrane review "vitamin C for asthma". 2013, http://hdl. handlenet/10138/40816.

doi:10.1186/1710-1492-10-58

Cite this article as: Hemilä: The effect of vitamin C on bronchoconstriction and respiratory symptoms caused by exercise: a review and statistical analysis. Allergy, Asthma \& Clinical Immunology 2014 10:58. 